\title{
Pendekatan Realistik Mangrove untuk Meningkatkan Hasil dan Minat Belajar Siswa pada Pelajaran Matematika di SD Pesisir Sampang
}

\author{
Chairul Fajar Tafrilyanto $^{(1)}$, Bambang Kurnadi ${ }^{(2)}$ \\ ${ }^{1}$ Dosen Prodi Pendidikan Matematika, ${ }^{2}$ Dosen Pertanian, Universitas Madura \\ Email : ${ }^{1}$ chairul_math@unira.ac.id, ${ }^{2}$ kurnadi@unira.ac.id
}

\begin{tabular}{l}
$\overline{\text { Tersedia Online di }}$ \\
\hline http://www.jurnal.unublitar.ac.id/ \\
index.php/briliant
\end{tabular}

Sejarah Artikel

Diterima pada 21 Oktober 2018

Disetuji pada 13 November 2018

Dipublikasikan pada 20

November 2018 Hal. 454-462

\begin{tabular}{l}
\hline Kata Kunci: \\
\hline Realistik, Mangrove, Minat dan \\
Hasil Belajar Matematika
\end{tabular}

\section{DOI:}

http://dx.doi.org/10.28926/brilian t.v3i3.246

\begin{abstract}
Abstrak: Tujuan penelitian ini yaitu mendeskripsikan pendekatan realistik mangrove untuk meningkatkan minat dan hasil belajar siswa pada pelajaran matematika di SD pesisir Sampang. Penelitian ini menggunakan dua siklus, dengan subjek penelitian siswa kelas II SDN Taddan II Sampang sebanyak 40 orang. Subjek tersebut dipilih berdasarkan masalah yang dihadapi siswa dalam pembelajaran matematika. Untuk memperoleh data digunakan tiga teknik pengumpulan data yaitu observasi, tes dan angket. Hasil dari penelitian yaitu Aktivitas belajar siswa selama proses pembelajaran menggunakan pendekatan realistik mangrove mengalami peningkatan sebesar 1,35 . Terlihat dari hasil observasi aktivitas siswa pada siklus I yaitu 1,82 dengan kategori cukup dan pada siklus II menjadi 3,17 dengan kategori baik. Respon siswa dalam penggunaan pendekatan realistik mangrove menunjukkan adanya peningkatan dengan persentase sebesar
\end{abstract} $18,09 \%$. Terlihat pada siklus I diperoleh persentase sebesar $73,41 \%$, dan pada siklus II menjadi $91,50 \%$. Respon siswa kedua siklus efektif karena yang menunjukkan minat yang baik terhadap pembelajaran menggunakan pendekatan realistik mangrove. Hasil belajar siswa dalam penggunaan pendekatan realistik mangrove juga mengalami peningkatan rata-rata sebesar 30,28 dan persentase ketuntasan belajar sebesar $52,4 \%$. Pada siklus I terdapat 37 siswa dengan nilai rata-rata 50,70. Sebanyak 13 siswa dinyatakan tuntas dengan persentase ketuntasan sebesar 35,10\%. Sedangkan Pada siklus II terdapat 40 siswa dengan nilai rata-rata 80,98 . Sebanyak 35 siswa dinyatakan tuntas dengan persentase ketuntasan sebesar $87,50 \%$.

\section{PENDAHULUAN}

Madura adalah nama pulau yang terletak di sebelah utara Jawa timur. Pulau Madura ini luasnya kurang lebih $5.250 \mathrm{~km}^{2}$, dengan penduduk sebanyak 4 juta jiwa. Madura terdiri dari 4 kabupaten antara lain : Bangkalan, Sampang, Pamekasan dan Sumenep. Madura yang menjadi satu dengan pulau Jawa bagian timur. Diantara ke empat kabupaten di Madura, menurut data dari kementrian pendidikan menyebutkan bahwa Angka Partisipasi Kasar (APK) pendidikan di Madura jauh dari APK Jawa Timur dan Nasional terutama Kabupaten Sampang. Kabupaten Sampang menduduki APK terendah di jawa Timur, berdasarkan data disdik Sampang sebanyak 1.302 anak usia sekolah tidak mengenyam pendidikan dan terpaksa memilih untuk putus sekolah. Jumlah anak putus sekolah tingkat SD/MI terdata sebanyak 657 orang siswa, SMP/MTs sebanyak 500 orang siswa, dan SMA/SMK/MA sebanyak 145. Alasan terbesar banyaknya anak di Madura yang putus sekolah adalah faktor pendidikan umum di nomor duakan, menikah

454 BRILIANT: Jurnal Riset dan Konseptual

Volume 3 Nomor 4, November 2018 
usia dini, dan merantau. Permasalahan pendidikan yang ada di Sampang terutama di daerah Pantai Utara (Sokobanah) maupun Selatan (Camplong) walaupun pemerintah menetapkan wajib belajar sembilan tahun, namun apa yang terjadi di lapangan tidak seperti yang diharapkan. Tingginya angka buta huruf akibat putus sekolah ini tidak terlepas dari rendahnya kesadaran masyarakat akan pentingnya pendidikan.

Selain rendahnya kesadaran masyarakat, proses pembelajaran yang dilakukan guru di kelas masih bersifat konvensional, metode yang digunakan tidak bervariasi tidak pernah mengaitkan dengan kehidupan siswa yang keseharian siswa termasuk tidak memanfaatkan lingkungan sekitar bermain siswa (Hasanah. 2014). Pantai Camplong yang memiliki panaroma yang indah, sepanjang jalan di pantai camplong ditumbuhi pepohonan mangrove, menambah kecantikan pantai tersebut. Berdasarkan keindahan tersebut, guru belum pernah memanfaatkan keindahan alam sekitar untuk dikaitkan dengan pembelajaran sehingga tidak dapat menumbuhkan minat belajar siswa.

Permasalahan-permasalahan tersebut selain akan berdampak pada rendahnya kualitas lulusan juga akan menjadi kendala tersendiri dalam implementasi program-program yang digalakkan oleh pemerintah dalam hal ini Kemendikbud. Salah satu program tersebut adalah perubahan-perubahan kurikulum yang mulai dari KBK (Kurikulum Berbasis Kompetensi) tahun 2004, KTSP (Kurikulum Kingkat Satuan Pendidikan) tahun 2008 dan yang terbaru adalah Kurikulum 2013. Setiap perubahan kurikulum yang sejatinya bertujuan untuk meningkatkan mutu pendidikan kurang mampu diimplementasikan dengan baik oleh guru-guru di kecamatan Campong. Jangankan mengimplementasikan, pemahaman guru-guru tentang kurikulum saja masih kurang, meskipun Dinas Pendidikan Kabupaten Sampang sudah memberikan sosialisasi pada mereka. Namun hal itu hanya sebatas teori saja, saat di kelas dalam proses belajar mengajar tidak ditemukan perubahan secara signifikan, sehingga peningkatan mutu pendidikan tetap tidak dapat tercapai.

Pada tahun 2014/2015 ini pemerintah telah merancang kurikulum tematik terintegratif yang mana harus dimasukkan budaya-budaya lokal dalam pembelajaransekolah, tidak terkecuali sekolah-sekolah di daerah Sampang. Inilah yang menjadi kekhawatiran penulis, "apakah sekolah-sekolah di daerah Sampang tersebut mampu mengimplementasikannya, dengan sederetan masalah-masalah pendidikan yang belum terselesaikan?". Dalam kurikulum nasional yang sejatinya akan diberlakukan tahun 2017 ini menekankan proses pembelajaran yang tematik integratif. Dengan demikian kebijakan ini akan hanya mampu dilaksanakan oleh sekolah-sekolah di perkotaan yang notabene memiliki sumber daya manusia dan sarana prasarana yang sangat mendukung, terutama pada pelajaran matematika,yang sampai saat ini nilai pelajaran matematika. Berdasarkan informasi dari UPTD Camplong, ada sekitar 65\% siswa di Kecamatan Camplong nilai pelajaran matematikanya di bawah KKM, hal ini dikuatkan oleh observasi yang dilakukan oleh peneliti di SDN Taddan II Kecamatan Camplong Kabupaten Sampang. Berdasarkan hasil wawancara dengan guru mata pelajaran matematika kelas II diperoleh informasiguru masih mendominasi pembelajaran. Guru sangat sering menggunakan pembelajaran konvensioal sehingga siswa pasif dalam proses pembelajaran matematika. Hal tersebut didukung oleh pemberian angket minat belajar siswa tehadap pembelajaran yang diberikan guru dengan persentase 
44,9\%. Persentase tersebut menunjukkan rendahnya minat siswa terhadap pembelajaran matematika yang telah diberikan oleh guru. Rendahnya minat siswa terhadap pembelajaran matematika menjadi salah satu faktor penyebab rendahnya hasil belajar matematika siswa. Salah satu materi matematika SD yaitu perkalian dan pembagian bilangan bulat sering membuat siswa kesulitan, karena metode yang selalu diberikan guru berupa hafalan pada perkalian dan pembagian kebalikan dari perkalian. Guru tidak memberikan suatu konsep bagaimana caranya agar siswa mengerti tetang konsep perkalian dan pembagian. Dengan menggunakan hafalan siswa tidak dapat membangun pengetahuannya sendiri sedangkan matematika mengharuskan siswa untuk melakukan kegiatan untuk memperoleh pengetahuan. Sehingga siswa harus diberi kesempatan agar dapat mengkonstruksi dan menghasilkan konsep matematika dengan cara dan bahasa mereka sendiri, guru juga belum mampu membuat suasana belajar yang menyenangkan bagi siswa sehingga hal tersebut membuat siswa tidak termotivasi untuk belajar serta guru pun menerangkan materi pelajaran matematika persis dengan materi yang ada di buku paket tanpa ada inovasi dari guru yang mana contoh-contoh soal yang ada didalam terkadang ada yang tidak dikenal siswa, padahal pembelajaran seharusnya lebih menekankan pembimbingan bagi siswa untuk menggunakan kesempatan menemukan kembali matematika dengan membawanya ke kehidupan mereka (USAID, 2015). Sehingga hal tersebut membuat membuat siswa sangat jenuh dalam mengikuti pelajaran matematika.

Berdasarkan latar belakang tersebut di atas maka penulis berkeinginan kuat untuk menerapkan suatu pendekatan pembelajaran dengan memperhatikan letak geografis, budaya dan segala kekurangan baik SDM maupun sarana prasarana yang dimiliki oleh sekolah masing-masing sangat diperlukan. didukung dengan pendapat Gravemeijer (1994:93) yang menggambarkan pembelajaran matematika dengan pendekatan realistik memanfaatkan masalah kontekstual yang mudah difahami siswa kemudian siswa diberi kesempatan seluas-luasnya untuk menyelesaikan masalah yang diberikan secara mandiri sesuai dengan pengetahuan awal yang dimilikinya. Sehingga dengan Pendekatan Realistik Mangrove pada pelajaran matematika diharapkan siswa yang sudah terbiasa melihat atau bermain di hutan mangrove dalam keseharian mereka merasa senang dalam mengkuti pelajaran matematika karena sangat dekat dengan kehidupan bermain mereka.

\section{METODE}

\section{Jenis Penelitian}

Penelitian ini merupakan penelitian tindakan kelas. Menurut Arikunto, dkk (2009:58) bahwa penelitian tindakan kelas adalah penelitian tindakan (action research) yang dilakukan dengan tujuan untuk memperbaiki mutu praktik pembelajaran di kelas. Model atau desain yang digunakan dalam penelitian ini adalah model Kemmis dan Taggart, dimana dalam satu siklus terdiri dari 4 komponen yaitu planning (perencanaan), acting (tindakan), observing (observasi) dan reflecting (refleksi).

\section{Lokasi dan Subjek Penelitian}

Penelitian dilaksanakan di salah satu SD daerah pesisir Sampang yaitu SDN Taddan II Sampang. Subjek dalam penelitian ini adalah siswa kelas II sebanyak 40 orang. Subjek dipilih berdasarkan masalah yang dihadapi siswa dalam pembelajaran matematika. 


\section{Instrumen dan Teknik Pengumpulan Data}

Instrumen yang digunakan untuk mengumpulkan data dalam penelitian ini meliputi lembar observasi aktivitas siswa, angket respon minat siswa dan tes hasil belajar. Pengumpulan data menggunakan 1) observasi pada saat proses pembelajaran berlangsung. Kegiatan yang diamati meliputi aktivitas siswa selama proses pembelajaran saat penggunaan pendekatan realistik mangrove. 2) Pemberian angket respon minat siswa. Angket diberikan setelah pembelajaran menggunakan pendekatan realistik mangrove untuk mengetahui minat siswa terhadap penggunaan pendekatan realistik mangrove. 3) Tes yang digunakan dalam penelitian ini berupa tes uraian yaitu soal atau pertanyaan yang diajukan pada responden berbentuk uraian. Tes diberikan setelah pembelajara menggunakan pendekatan realistik mangrove untuk melihat ketuntasan belajar induvidual dan ketuntasan belajar klasikal.

\section{Teknik Analisis Data}

Teknik analisis data dalam penelitian ini meliputi 1) analisis hasil observasi aktivitas belajar siswa pada saat pembelajaran menggunakan pendekatan realistik mangrove dengan menggunakan rumus $N A=\frac{\Sigma_{n}}{\Sigma_{\Omega}}$ (Arikunto, 2009:19) dengan Nilai akhir (NA), Nilai setiap aspek yang diamati ( $n$ ) dan Aspek yang diamati (a). Untuk kriteria penilaian yaitu bobot 4 (A), bobot 3 (B), bobot 2 (C) dan bobot 1 (D). Sedangkan kategori penentuan nilai akhir sebagai berikut 0,00 - 1,49 kategori kurang, 1,50 - 2,49 kategori cukup, 2,50 - 3,49 kategori baik dan 3,50 - 4,00 kategori sangat baik. 2) analisis hasil angket respon minat siswa setelah pembelajaran menggunakan pendekatan realistik mangrove dengan menggunakan rumus $\frac{\text { Jumlah respon minat siswa tiap aspek yang muncul }}{\text { Jumlah seluruh siswa }} \times 100 \%$ (Trianto, 2009: 243). Siswa dikatakan berminat terhadap pembelajaran realistik mangrove, jika jawaban siswa terhadap pernyataan positif untuk setiap aspek yang direspon pada setiap komponen pembelajaran diperoleh persentase $\geq 70 \%$. 3) analisis tes hasil belajar siswa setelah pembelajaran menggunakan pendekatan realistik mangrove untuk ketuntasan belajar secara individual menggunakan rumus $K B I=\frac{\text { Skor test }}{\text { Skor maksimal }} \times 100 \%$ (Trianto, 2009:241), ketuntasan belajar individual tercapai jika setiap mahasiswa memperoleh minimal 75. Sedangkan untuk ketuntasan belajar secara klasikal menggunakan rumus $K B K=\frac{\text { Jumlah siswa yang tuntas }}{\text { Jumiah seluruh siswa }}$ (Trianto, 2009:241), ketuntasan belajar klasikal tercapai ketika dalam suatu kelas terdapat $85 \%$ siswa yang telah mencapai ketuntasan belajar secara individual.

\section{HASIL}

\section{Siklus I}

Berdasarkan hasil pengamatan selama pelaksanaan kegiatan pembelajaran pada siklus I, hasil observasi peneliti diperoleh sebagai berikut:

Kegiatan siswa pada pertemuan pertama siklus I siswa masih banyak yang kurang aktif pada saat pembelajaran menggunakan pendekatan realistik mangrove. Pada kegiatan awal siswa kurang memusatkan perhatian pada apa yang disampaikan guru. Nampak aktivitas siswa masih banyak yang berbicara sendiri, 
secara kompak teriak "pohon tenjeng" ketika melihat gambar pohon LKS, siswa kurang antusias, membuka lembaran pada LKS hanya untuk melihat gambargambar dan kurang mempunyai minat untuk belajar matematika.

Pada tahap memahami masalah kontekstual, siswa langsung menjawab deskripsi pertanyaan pada LKS dengan kata "kan tenjeng" yaitu bahasa seharibagi mereka untuk menyebut pohon mangrove. Sebagian siswa masih kebingungan dalam memahami tulisan yang ada pada LKS, karena penguasaan kebahasaan siswa sangat minim, sehingga siswa kesulitan dalam memahami kalimat pada masalah 1 sampai 5. Siswa lebih fokus terhadap gambar hewanhewan laut yang ada pada LKS.

Pada tahap menyelesaikan masalah, sebagian besar siswa masih belum bisa menyelesaikan masalah yang ada pada LKS karena siswa tidak memahami makna dari permasalahan-permasalahan yang diberikan pada LKS. Penyelesaian masalah sulit dilakukan karena siswa merasa kesulitan dalam memaknai bahasa soal. Beberapa siswa tidak dapat mengerjakan sendiri sehingga masih mecontek pekerjaan temannya. Guru juga kesulitan dalam memantau masing-masing siswa dalam menyelesaikan masalah karena jumlah siswa terlalu banyak yaitu berjumlah 40 orang. Pada kegiatan ini terlalu banyak memakan waktu sehingga melebihi waktu yang sudah ditentukan.

Pada membandingkan dan mendiskusikan jawaban, beberapa siswa sibuk berbicara sendiri tanpa memperhatikan petunjuk guru untuk mendiskusikan jawaban sesama teman dalam kelompok.

Pada tahap menarik kesimpulan, siswa masih belum bisa menarik kesimpulan dari 3 kesimpulan yang harus dibuat pada LKS. Guru masih berperan dalam membimbing siswa dalam memberi kesimpulan tapi kesimpulannya masih salah. Guru memberikan konsep yang salah ketika mengatakan makna 3 x 4 sama dengan 4 x 5 dilihat dari kesimpulan perkalian merupakan penjumlahan berulang.

Pada kegiatan akhir pembelajaran dimana guru memberikan beberapa latihan untuk mengetahui sejauh mana siswa memahami materi perkalian. Ternyata sebagian besar siswa memengeluh dan siswa belum bisa mengerjakan soal latihan dengan benar.

\section{Siklus II}

Berdasarkan hasil pengamatan selama pelaksanaan kegiatan pembelajaran pada siklus II, hasil observasi peneliti diperoleh sebagai berikut:

Kegiatan siswa pada pertemuan pertama siklus II siswa sudah mulai lebih aktif pada saat pembelajaran menggunakan pendekatan realistik mangrove. Pada kegiatan awal siswa sudah memusatkan perhatian pada apa yang disampaikan guru. Nampak aktivitas siswa sudah tidak berbicara sendiri, siswa sangat antusias, siswa membuka lembaran pada LKS untuk melihat gambar-gambar, membaca pengetahuan-pengetahuan yang ada pada LKS dan mulai berminat untuk belajar matematika.

Pada tahap memahami masalah kontekstual, siswa sudah tidak kebingungan dalam memahami tulisan yang ada pada LKS, karena sekali-kali guru menterjemahkan kalimat-kalimat dalam LKS dalam bahasa madura sehingga siswa tidak lagi kesulitan dalam memahami kalimat pada masalah 1 sampai 3 . Siswa lebih fokus terhadap apa yang disampaikan guru sesuai dengan yang ada pada LKS. 
Pada tahap menyelesaikan masalah, sebagian besar siswa sudah bisa menyelesaikan masalah yang ada pada LKS karena sudah bisa memahami makna dari permasalahan-permasalahan yang diberikan pada LKS. Penyelesaian masalah tidak sulit lagi bagi siswa merasa karena guru sudah mengatasi kesulitan tersebut dalam bahasa madura. Sebagian besar siswa sudah bisa mengerjakan sendiri sehingga tidak mencontek pekerjaan temannya. Siswa mulai percaya diri dalam mengerjakan soal sendiri. Guru masih tetap kesulitan dalam memantau masingmasing siswa dalam menyelesaikan masalah karena jumlah siswa terlalu banyak yaitu berjumlah 40 orang. Pada kegiatan ini terlalu banyak memakan waktu sehingga lebih 10 menit dari waktu yang ditentukan.

Pada membandingkan dan mendiskusikan jawaban, beberapa siswa mulai berdiskusi dengan baik, siswa tidak lagi sibuk berbicara sendiri serta memperhatikan petunjuk guru. Siswa memprsentasikan jawabanya dengan rasa percaya diri.

Pada tahap menarik kesimpulan, siswa sudah bisa menarik kesimpulan yang harus dibuat pada LKS. Guru masih berperan dalam membimbing siswa dalam memberi kesimpulan tapi kesimpulannya masih salah. Siswa membuat kesimpulan perkalian merupakan penjumlahan berulang.

Pada kegiatan akhir pembelajaran dimana guru memberikan beberapa latihan untuk mengetahui sejauh mana siswa memahami materi perkalian. Sebagian besar siswa sangat mengerjakan soal latihan dengan benar. Siswa juga mulai merasa senang untuk mengerjakan pekerjaan rumah (PR).

Hasil penelitian yang berupa data hasil observasi aktivitas siswa, data hasil angket respon minat siswa, dan data hasil tes siswa menggunakan pendekatan realistik mangrove untuk meningkatkan minat dan hasil belajar siswa pada materi pokok perkalian dan pembagian bilangan bulat di SDN Taddan II Sampang. Berdasarkan hasil observasi, respon minat siswa, dan tes yang telah dilakukan diperoleh hasil sebagai berikut.

Berdasarkan data yang diperoleh dari hasil observasi aktivitas siswa pada siklus I dan siklus II di atas menunjukkan adanya peningkatan rata-rata aktivitas siswa dalam pembelajaran menggunakan pendekatan realistik mangrove sebesar 1,35. Pada siklus I diperoleh rata-rata sebesar 1,82 yang berkategori cukup, sedangkan pada siklus II diperoleh rata-rata sebesar 3,17 yang berkategori baik yang ditunjukkan dalam diagram berikut :

Diagram Hasil Observasi Aktivitas Siswa

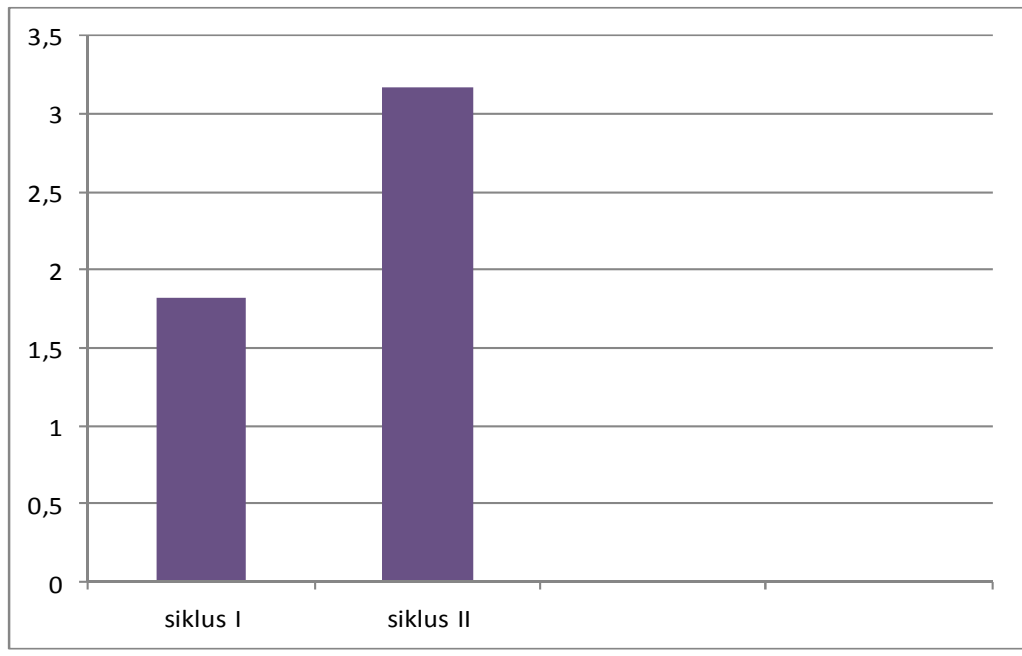

BRILIANT: Jurnal Riset dan Konseptual Volume 3 Nomor 4, November 2018 
Berdasarkan hasil analisis data respon siswa menunjukkan adanya peningkatan dari siklus I ke siklus II dengan persentase sebesar 18,09\%. Pada siklus I diperoleh persentase sebesar 73,41 \%, sedangkan pada siklus II terjadi peningkatan menjadi 91,50\%. Respon siswa kedua siklus efektif karena yang menunjukkan minat yang baik terhadap pembelajaran menggunakan pendekatan realistik mangrove. yang ditunjukkan dalam diagram berikut :



Berdasarkan analisis tes hasil belajar siswa, menunjukkan adanya peningkatan rata-rata hasil belajar dan ketuntasan hasil belajar dari siklus I ke siklus II sebesar 30,28 dan 52,36\%. Pada siklus I diperoleh rata-rata hasil belajar 50,70 dengan persentase ketutasan hasil belajar sebesar $35,14 \%$, sedangkan pada siklus I diperoleh rata-rata hasil belajar 80,98 dengan persentase ketutasan hasil belajar sebesar 87,50 \%. Sehingga pembelajaran menggunakan pendekatan realistik mangrove dikatakan sukses.

\section{Diagram Hasil Tes Siswa}

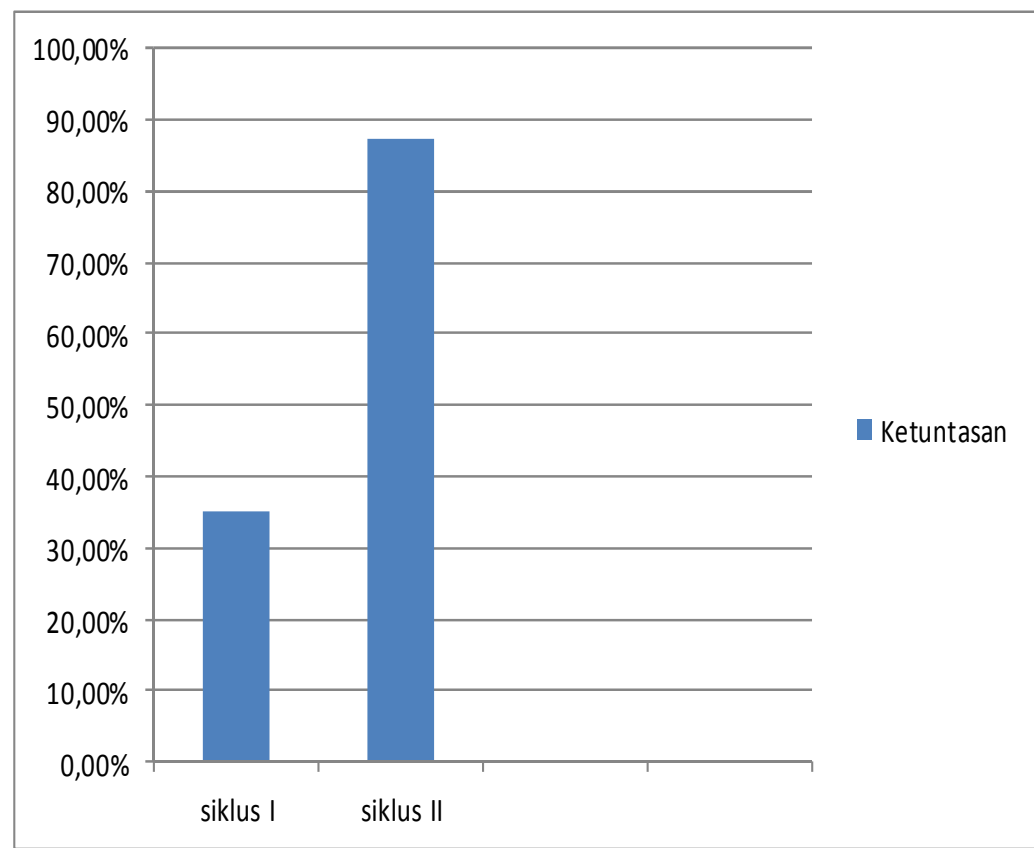

460 BRILIANT: Jurnal Riset dan Konseptual

Volume 3 Nomor 4, November 2018 
Penelitian ini merupakan penelitian tindakan kelas yang bertujuan untuk meningkatkan minat dan hasil belajar siswa dalam pembelajaran. Berdasarkan hasil observasi awal sebelum tindakan diperoleh hasil dan minat belajar siswa kelas II SDN Taddan II Sampang masih rendah.

Setelah mengkaji dari hasil wawancara dengan guru kelas sebelum tindakan tersebut, peneliti dan guru melakukan tindakan pada siklus I dan II yaitu menggunakan pendekatan realistik mangrove. Upaya peningkatan minat dan hasil belajar siswa yang dilakukan peneliti pada materi perkalian dan pembagian bilangan bulat di kelas II SDN Taddan II Sampang pada akhirnya berjalan lancar setelah dilaksanakan tindakan pada siklus I dan II, meskipun pada awal pembelajaran suasana kelas masih dalam taraf penyesuaian siswa mengikuti pembelajaran yang peneliti gunakan. Para siswa belum terbiasa belajar menggunakan pendekatan realistik mangrove. Dengan adanya kerjasama dan bimbingan yang diberikan guru, hal ini dapat diselesaikan dengan baik. Secara umum guru telah berhasil dalam pengelolan kelas dan membuat lebih siswa aktif dengan penggunaan pembelajaran realistik mangrove.

\section{KESIMPULAN DAN SARAN \\ Kesimpulan}

Berdasarkan hasil penelitian yang telah dilakukan, dapat dibuat kesimpulan bahwa aktivitas belajar siswa selama proses pembelajaran menggunakan pendekatan realistik mangrove untuk meningkatkan hasil belajar siswa pada materi perkalian dan pembagian bilangan bulat di kelas II SDN Taddan Sampang mengalami peningkatan yang signifikan. Hal ini dapat dilihat dari hasil observasi aktivitas siswa pada siklus I yaitu 1,82 dengan kategori cukup dan pada siklus II menjadi 3,17 dengan kategori baik.

Respon siswa dalam penggunaan pendekatan realistik mangrove untuk meningkatkan hasil belajar siswa pada materi perkalian dan pembagian bilangan bulat di kelas II SDN Taddan Sampang menunjukkan adanya peningkatan dari siklus I ke siklus II dengan persentase sebesar 18,09\%. Pada siklus I diperoleh persentase sebesar $73,41 \%$, sedangkan pada siklus II terjadi peningkatan menjadi $91,50 \%$. Respon siswa kedua siklus efektif karena yang menunjukkan minat yang baik terhadap pembelajaran menggunakan pendekatan realistik mangrove.

Hasil belajar siswa dalam penggunaan pendekatan realistik mangrove untuk meningkatkan hasil belajar siswa pada materi perkalian dan pembagian bilangan bulat di kelas II SDN Taddan Sampang. terdapat peningkatan hasil belajar siklus I ke siklus II dengan rata-rata sebesar 30,28 dan persentase ketuntasan belajar sebesar 52,36\%. Pada siklus I terdapat 37 siswa dengan ratarata hasil belajar 50,70. Sebanyak 13 siswa dinyatakan tuntas dan 24 siswa dinyatakan tidak tuntas dengan persentase ketuntasan sebesar 35,10\%. Sedangkan Pada siklus II terdapat 40 siswa dengan rata-rata hasil belajar 80,98. Sebanyak 35 siswa dinyatakan tuntas dan 5 siswa dinyatakan tidak tuntas dengan persentase ketuntasan sebesar $87,50 \%$. 


\section{Saran}

Saran yang dapat diberikan peneliti sebagai sumbangan pemikiran terhadap penggunaan pendekatan realistik mangrove khususnya dalam pembelajaran matematika adalah sebagai berikut:

Perangkat pembelajaran menggunakan pendekatan realistik mangrove hendaknya dikembangkan untuk pokok bahasan matematika yang lain utamanya matematika untuk sekolah dasar, karena berdasarkan hasil angket respon minat siswa diperoleh bahwa siswa senang mengikuti pembelajaran menggunakan pendekatan realistik mangrove.

Pembagian waktu dalam melaksanakan proses pembelajaran matematika menggunakan pendekatan realistik mangrove lebih diperhatikan lagi, sehingga semua langkah-langkah pembelajaran dapat terlaksana. Akan lebih baik jika alokasi waktu dalam pembelajaran ditambah agar pelaksanaan pembelajaran bisa berjalan secara maksimal.

Perangkat pembelajaran menggunakan pendekatan realistik mangrove hendaknya dipergunakan oleh para pendidik yang mengajar di daerah pesisir sebagai upaya meningkatkan kualitas pendidikan khususnya pendidikan matematika.

\section{DAFTAR RUJUKAN}

Arikunto, Suharsimi. 2009. Prosedur Penelitian Suatu Pendekatan Praktek. Jakarta : Rineka Cipta

Daitin Tarigan. (2006). Pembelajaran Matematika Realistik. Jakarta: Depdiknas.

Gravemeijer, K. 1994. Developing Realistic Mathematics Education. Ultrecht: Freudenthal Institute

Hasanah, Sri Indriati. 2014. Pengembangan perangkat Pembelajaran Matematika Realistik Bernuansa Islami di MTs . Jurnal Interaksi, 8(1):15-20

Hasanah, Sri Indriati. 2014. Sumber Belajar Matematika dari Lingkungan Alam Sekitar Berbasis Pondok Pesantren. Jurnal Interaksi, 9(1 ): 28-31

Hasanah, Sri Indriati. 2014. Pembelajaran Matematika Realistik bernuansa Islami Pada Pokok Bahasan Bangun Sisi Datar Kelas VIII MTs. Jurnal Interaksi ,10(2): 134-138

Hasanah, Sri Indriati. 2015. Realistics Mathematics Education With The Sense Of Madurase Culture. Makalah disampaikan di Seminar Internasional Universitas Negeri Makassar

Soedjadi, R. 2001. Pemanfaatan Realitas dan Lingkungan Dalam Pembelajaran Matematika. Makalah Seminar Nasional. FMIPA Unesa

Trianto.2009. Mengembangkan Model Pembelajaran Tematik. Jakarta: PT. Prestasi Pustakaraya

USAID. 2015. Sumber Buku untuk Dosen LPTK. Pembelajaran Matematika $S D / M I$ di LPTK. Indonesia: RTI International. 